\title{
Polymer blend particles with defined compositions for targeting antigen to both class I and II antigen presentation pathways
}

\author{
Kenny K. Tran\#, Xi Zhan\#, and Hong Shen * \\ Department of Chemical Engineering, University of Washington, Campus Box 351750, Seattle, \\ WA 98195
}

\section{Abstract}

Defense against many persistent and difficult-to-treat diseases requires a combination of humoral, $\mathrm{CD}^{+}$and $\mathrm{CD} 8^{+} \mathrm{T}$ cell responses, which necessitates targeting antigens to both class I and II antigen presentation pathways. In this study, we developed polymer blend particles by mixing two functionally unique polymers, poly(lactide-co-glycolide) (PLGA) and a pH-responsive polymer, poly(dimethylaminoethyl methacrylate-co-propylacrylic acid-co-butyl methacrylate) (DMAEMAco-PAA-co-BMA). We showed polymer blend particles enabled the delivery of antigens into both class I and II antigen presentation pathways in vitro. Increasing the ratio of the $\mathrm{pH}$-responsive polymer in blend particles increased the degree of class I antigen presentation, while maintaining high levels of class II antigen presentation. In a mouse model, we demonstrated that a significantly higher and sustained level of $\mathrm{CD} 4^{+}$and $\mathrm{CD} 8^{+} \mathrm{T}$ cell responses, and comparable antibody responses, were elicited with polymer blend particles than PLGA particles and a conventional vaccine, Alum. The polymer blend particles offer a potential vaccine delivery platform to generate a combination of humoral and cell-mediated immune responses that insure robust and long-lasting immunity against many infectious diseases and cancers.

\section{Keywords}

adjuvant; antigen presentation; cross-presentation; blend polymers; vaccines

\section{Introduction}

A breadth of long-lasting immune responses, including humoral and cell-mediated immunity, are essential to combat persistent and difficult-to-treat diseases such as acquired immune deficiency syndrome (AIDS), malaria, and cancers. ${ }^{[1-3]}$ Generating broad and robust immune responses requires the interactions between a number of key cell types, including antigen presentation cells (APCs), B cells, and T cells. Central to these interactions are APCs, in particular dendritic cells (DCs). ${ }^{[4]}$ APCs provide T cells with three signals required for their activation, differentiation and survival. ${ }^{[5,6]}$ Signal 1 is the peptideMHC I or II complex that enables antigen-specific activation of $\mathrm{CD}^{+}$or $\mathrm{CD}^{+} \mathrm{T}$ cells, respectively; signal 2 is the interaction of co-stimulatory molecules on the APC surface with

Copyright WILEY-VCH Verlag GmbH \& Co. KGaA, 69469 Weinheim, Germany, 2012.

*Corresponding author; hs24@uw.edu.

${ }^{\#}$ The authors contributed equally to this work. 
corresponding molecules on T cells and signal 3 is soluble cytokines. Depending on the combination of all three signals, $\mathrm{CD} 4^{+} \mathrm{T}$ cells can differentiate into $\mathrm{Th}_{1}$ or $\mathrm{Th}_{2}$ helper cells. ${ }^{[7]}$ Primary $\mathrm{CD}^{+} \mathrm{T}$ cell responses require similar signals as $\mathrm{CD} 4^{+} \mathrm{T}$ cells whereas the generation of memory $\mathrm{CD} 8^{+} \mathrm{T}$ cells requires $\mathrm{CD} 4^{+} \mathrm{T}$ cell help. ${ }^{[8]} \mathrm{B}$ cells themselves are also able to internalize antigens and become plasma $\mathrm{B}$ cells that secrete antigen-specific antibodies upon the activation by antigen-specific $\mathrm{CD} 4{ }^{+} \mathrm{T}$ cells. ${ }^{[9,10]}$

Signal 1 is the pre-requisite for coordinating the interactions of key cells. ${ }^{[4]}$ Exogenously delivered antigen able to access the early endosomal pathway or cytosol can be degraded and loaded onto MHC class I molecules in a process known as cross-presentation, leading to $\mathrm{CD}^{+} \mathrm{T}$ cell stimulation. ${ }^{[11,12]}$ Antigen routed to late endosomes/lysosomes is further degraded and loaded onto MHC class II molecules, leading to $\mathrm{CD}^{+} \mathrm{T}$ cell stimulation. ${ }^{[13-15]}$ The ability of antigen to access the intracellular spatial compartments, namely, class I and II antigen presentation pathways in APCs dictates the strength and polarity (MHC I/peptide vs. MHC II/peptide) of signal 1.

Several particulate systems made from $\mathrm{pH}$-insensitive polymers have been utilized for the delivery of antigen. ${ }^{[16-19]}$ Although they enhance the cellular uptake and access to class I and II pathways compared to soluble form of antigens, they are generally inefficient in accessing class I pathways. ${ }^{[20]}$ Recent efforts have been focused on $\mathrm{pH}$-responsive and redox-sensitive polymers that enable antigen release from endosomal/lysosomal compartments and allow antigen to effectively access the classical class I antigen presentation pathway in the cytosol. ${ }^{[21-23]}$ However, these systems potentially reduce the opportunity of antigen to access the class II antigen presentation pathway.

We hypothesized that antigen could be routed to class I and II antigen presentation pathways if we controlled its delivery to cytosolic and endosomal compartments. To test our hypothesis, we developed a particulate antigen delivery platform derived from the blend of two polymers, PLGA and poly(DMAEMA-co-PAA-co-BMA). PLGA has been widely used in drug and vaccine delivery vectors because of its biodegradable and biocompatibility properties. ${ }^{[24]}$ As a model polymer, we used poly(DMAEMA-co-PAA-co-BMA), which exhibits membrane lytic function in a $\mathrm{pH}$ dependent manner. ${ }^{[25]}$ Compared to single polymer-based systems, polymer blends offer great flexibility in modulating morphology, hydrophobicity for accommodating different cargos and environmental responsiveness without involving complex syntheses. Here, we demonstrated that this platform routed antigen to both class I and class II antigen presentation pathways in vitro in a compositiondependent manner. Correspondingly, we were able to generate both primary and memory immune antibody and $\mathrm{T}$ cell responses in vivo.

\section{Results}

\subsection{Choice of polymers for protein antigen, ovalbumin (OVA)}

Two polymers, PLGA and a pH-responsive terpolymer DMAEMA-co-PAA-co-BMA, were chosen to fabricate blend particles to deliver OVA. In the terpolymer, Dimethylaminoethyl methacrylate (DMAEMA) has a pKa of 8.3, and 2-alkylacrylic acids (i.e. PAA) have a pKa of $5 \sim 7$. Homopolymers of DMAEMA and 2-alkylacrylic acids have been used for 
intracellular delivery of agents. ${ }^{[26]}$ BMA changes the hydrophobicity of polymers, and has been shown to increase transfection efficiency of polymeric gene carriers. ${ }^{[27]}$ Due to its hydrophobicity, it is expected to facilitate the mixing with PLGA. Initially, we investigated how the ratio of DMAEMA and alkylacrylic acids affected the size and stability of particles and the efficiency of antigen presentations (Supplemental Figure 1) by using blend particles fabricated with PLGA and dipolymers made from butyl methacrylate (BMA) and either DMAEMA or acrylic acid (AA). For ovalbumin (OVA), the blend particles made from poly(BMA-AA) were poor in both class I and II antigen presentation; the blend particles made from poly(BMA-DMAEMA) were efficient in both class I and II antigen presentation but were not stable during storage and formed aggregates. Built upon these observations, we decided to choose poly(DMAEMA-co-PAA-co-BMA) with a 1:1:2 molar ratio to investigate how the fraction of $\mathrm{pH}$-sensitive polymer affects antigen presentations and subsequently immune responses in this study. We would like to note that 2-Propylacrylic acid (PAA) for subsequent study was chosen instead of AA because previous studies have shown that copolymers containing PAA were more efficient in inducing the escape of cargos from endolysosomal compartments. ${ }^{[28]}$

\subsection{Characterization of polymer blend particles}

The amount of terpolymer in the particles were controlled through the ratio of polymers used in the double emulsion fabrication process, as confirmed through NMR analysis (Table 1). With increasing weight ratio of the terpolymer used in the fabrication process, increasing amounts of the $\mathrm{pH}$-responsive terpolymer were successfully incorporated into blend particles. Approximately $90-100 \%$ of the terpolymer was successfully incorporated. Particles composed of only PLGA had an average diameter of $\sim 275 \mathrm{~nm}$ with a polydispersity index (PDI) of 0.08. 0.2 and 0.5 blend particles (particles containing 0.2 and 0.5 weight fraction terpolymer, respectively) had an average diameter of 400 and $650 \mathrm{~nm}$ (Figure 1a), respectively. Particles also possessed a spherical morphology at all weight ratios (Figure 1d). 0.5 blend particles exhibited a larger hydrodynamic diameter as measured by dynamic light scattering compared to PLGA due to the charged and flexible side chains present on the terpolymer while in solution. In contrast, for scanning electron microscope (SEM) images, the samples were dried and imaged in a dry state, which yielded smaller diameters compared to hydrodynamic diameters. The $\mathrm{pH}$-responsive terpolymer alone could not be fabricated into particles, indicating that the presence of PLGA was critical for the formation of well-dispersed particles (data not shown).

The zeta potential of particles at pH 6.0 was shown in Figure 1c. PLGA particles had a slightly negative zeta potential. Both 0.2 and 0.5 blend particles had zeta potentials of approximately $+27 \mathrm{mV}$. The pKa of DMAEMA and PAA is 8.3 and 6.7 , respectively. ${ }^{[29,30]}$ At pH 6.0, DMAEMA becomes ionized and positively charged. All the blend particles appeared positively charged at $\mathrm{pH} 6.0$, confirming that the $\mathrm{pH}$-responsive terpolymer was incorporated into blend particles, and that components of the terpolymer, such as DMAEMA, may be displayed on the particle surface. 


\subsection{Release of OVA antigen from blend particles}

Antigen released from PLGA particles is characterized by a burst release followed by a phase of slower release controlled by particle degradation. ${ }^{[31]}$ Depending on the size of the particles, the majority of the antigen may be released in the initial burst phase. ${ }^{[32,33]}$ OVA has a pKa of 4.6. At pH 6 and 7.4, it exhibits negative charge while DMAEMA exhibited positive charge. The charged moieties present on the terpolymer in blend particles were expected to interact with OVA through electrical static interaction, potentially limiting any burst release and leading to gradual antigen release controlled by particle degradation. We examined the release of OVA from PLGA and polymer blend particles at $\mathrm{pH}$ 7.4, 6 and 4.6 (Supplemental Figure 2). $\mathrm{pH} 7.4$ mimics the $\mathrm{pH}$ environment of extracellular space, and $\mathrm{pH}$ 6 and 4.6 are similar to the $\mathrm{pH}$ in endosomal and lysosomal compartments. As expected, at pH 7.4 and 6, OVA release from PLGA particles displayed a higher level of initial burst while blend particles exhibited more sustained and slow release within the first week. No difference in the release of OVA was observed from PLGA particles and blend particles.

\subsection{Blend particles mediate endosomal escape of co-delivered cargos}

We next examined the ability of blend particles to mediate the endosomal escape of codelivered cargos. Calcein is a membrane-impermeable fluorescent dye that is internalized by cells into endosomal/lysosomal compartments. When co-delivered with agents that result in endosomal escape and leakage, calcein diffuses into the cytosolic. ${ }^{[21]}$ When calcein was delivered alone to DC2.4 cells, it appears punctate, indicating that endosomal membranes are intact; similar results are obtained when calcein was co-delivered with either inert polystyrene beads (PS) or PLGA particles (Figure 2). In contrast, 0.2 and 0.5 blend particles induced endosomal escape of calcein, leading to a diffuse pattern of calcein within the cytosolic space of cells (Figure 2). It is possible that blend particles may cause cell death and compromise the integrity of cell membranes. As a result, calcein may directly entered cytosolic space through the permeable cell membrane. We examined the viability of cells by using a cell-impermeable dye (Supplemental Figure 3). Cells were exposed to blend particles at the concentration used in the experiment did not cause cytotoxicity; thus, cytosolic calcein was not caused by the enhanced membrane permeability caused by cell death. These results demonstrate that the blend particles were able to induce the escape or leakage of co-delivered cargos from endosomal compartments.

We next examined the intracellular delivery of a model antigen, ovalbumin (OVA), mediated by blend particles into either endosomal/lysosomal compartments or the cytosol. Blend particles were fabricated incorporating fluorescent quantum dots and OVA-FITC. Quantum dots are hydrophobic and remained within particles, allowing the tracking of particles within cells. After being endocytosed by cells, the majority of FITC-OVA and PLGA particles were co-localized (Figure 3a), mainly in late endosomes/lysosomes (Figure $3 \mathrm{c}, \mathrm{e}$ ). For 0.5 blend particles, fluorescence (green) from FITC-OVA molecules was observed and appeared in a distinct location from where particles were (Figure 3b). These FITC-OVA molecules were not co-localized with endosomal or lysosomal compartments (Figure 3d, f), indicating the escape of FITC-OVA molecules from particles into the cytosolic space. A fraction of encapsulated FITC-OVA molecules were still trapped in particles and trafficked together with particles to late endosomes/lysosomes, which appeared 
as white (Figure 3f). The pixels that appeared as magenta indicate that some 0.5 blend particles residing in lysosomes released most of their FITC-OVA. These results suggest that blend particles are able to mediate the escape of a fraction antigen while a fraction of antigen remains in endosomal/lysosomal compartments.

\subsection{Blend particles mediate both class I and II antigen presentation in vitro}

We next examined the ability of blend particles to route incorporated antigen to both the class I and II antigen presentation pathways for the stimulation of $\mathrm{CD} 8^{+}$and $\mathrm{CD} 4^{+} \mathrm{T}$ cells, respectively. We used cell culture systems where only the peptide-MHC I or MHC II signal (Signal 1) is necessary to activate T cells. ${ }^{[34]}$ OVA was successfully incorporated into all blend particles with protein loadings ranging from 35-55 $\mu$ g OVA / mg polymer (Table 1). Blend particles effectively shuttled antigen to the class II antigen presentation pathway compared to PLGA particles at the antigen doses examined (Figure 4a). 0.2 blend particles showed higher $\mathrm{CD}^{+} \mathrm{T}$ cell stimulation compared to 0.5 blend particles at all of the antigen doses examined, suggesting that incorporation of higher amounts of the pH-responsive terpolymer in the blend particles led to lower antigen availability for the class II antigen presentation pathway.

We also examined the effect of blend particles on $\mathrm{CD}^{+} \mathrm{T}$ cell stimulation (Figure $4 \mathrm{~b}$ ). Again, blend particles were more effective than PLGA particles for the antigen doses examined. For all the antigen doses examined, the 0.5 blend particles led to higher $\mathrm{CD} 8^{+} \mathrm{T}$ cell stimulation compared to 0.2 blend particles. This demonstrates that incorporation of higher ratios of the $\mathrm{pH}$-responsive terpolymer in blend particles led to more antigen availability for the class I antigen presentation pathway, most likely the cytosolic pathway. We also examined the effect of blend particles on the uptake of antigen. Although blend particles did slightly increase the uptake of antigen at high antigen doses ( $>0.5 \mu \mathrm{g} / \mathrm{ml})$, there were no significant differences in uptake at lower antigen doses (data not shown). Therefore, differences in antigen uptake cannot completely explain the differences in antigen presentation efficiencies mediated by blend particles. Thus, blend particles are able to mediate both class I and II antigen presentation in a composition-dependent manner.

\subsection{Blend particles induced both primary and memory antibody responses in vivo}

We examined the ability of blend particles to induce antibody responses in an in vivo mouse model. OVA mixed with the adjuvant aluminum hydroxide (Alum) was used as a positive control. ${ }^{[35]}$ We initially examined anti-OVA IgG responses induced by particles after subcutaneous injection (hock) at weeks 0 and 2 (Figure 5a). $3 \mathrm{~d}$ post-boost immunization, Alum resulted in a robust antibody response as expected, while all particles resulted in relatively lower antibody responses (Figure 5a). Antigen incorporated in blend particles resulted in stronger antibody responses compared to free antigen regardless of particle composition. 0.2 and 0.5 blend particles resulted in approximately five-fold higher antibody titers compared to PLGA particles. We also assessed the memory antibody response $60 \mathrm{~d}$ post-boost immunization (Figure 5b). Again, Alum generated the strongest antibody response. For the blend particles, the level of antibody generated was dependent on the composition. PLGA particles resulted in the lowest level of antibody, followed by 0.2 and 0.5 blend particles. Surprisingly, the antibody response by 0.5 blend particles increased to 
the same order of magnitude as the Alum. Thus, blend particles are able to induce robust memory antibody responses in a composition-dependent manner, and levels were comparable to those generated by Alum.

\subsection{Blend particles induce primary $T$ cell responses in vivo}

We next examined the ability of blend particles to induce primary antigen-specific $\mathrm{CD} 4^{+}$ and $\mathrm{CD} 8^{+} \mathrm{T}$ cells in both draining lymph nodes and spleens (Figure 6). Although Alum induced robust antibody responses, the level of $\mathrm{T}$ cell response was low compared to blend particles. For antigen-specific $\mathrm{CD} 4^{+} \mathrm{T}$ cells, blend particles induced higher levels compared to soluble OVA and Alum. However, there was no statistically significant difference in the level of $\mathrm{T}$ cells generated in either spleen or draining lymph nodes by different compositions of blend particles. For antigen-specific $\mathrm{CD}^{+} \mathrm{T}$ cells in the spleen, however, 0.5 blend particles generated the highest levels compared to all other formulations (Figure 6d). No statistically significant difference in the level of $\mathrm{CD}^{+} \mathrm{T}$ cells by different particle formulations was observed for lymph node organs. Thus, blend particles are able to generate robust $\mathrm{T}$ cell responses, and 0.5 blend particles were superior in generating primary $\mathrm{CD} 8^{+} \mathrm{T}$ cell responses in the spleen.

\subsection{Memory responses induced by antigen-loaded blend particles}

We next examined the ability of blend particles to stimulate memory $\mathrm{CD} 4^{+}$and $\mathrm{CD} 8^{+} \mathrm{T}$ cells in both spleen and lymph node organs $60 \mathrm{~d}$ post-boost vaccination (Figure 7). For lymph nodes, 0.2 and 0.5 blend particles generated equivalent levels and had higher memory $\mathrm{CD}^{+} \mathrm{T}$ cell responses than other formulations; all the polymeric particles produced a higher level of memory $\mathrm{CD} 8^{+} \mathrm{T}$ cell responses than Alum. For the spleen, 0.5 blend particles generated the highest level of both $\mathrm{CD} 4^{+}$cells and $\mathrm{CD} 8^{+} \mathrm{T}$ cells. Most interestingly, 0.5 blend particles were suerpior to Alum and other particles in maintaining long-lasting memory $\mathrm{CD} 4^{+}$and $\mathrm{CD} 8^{+} \mathrm{T}$ cells in both spleen and draining lymph nodes.

\subsection{Internalization of blend particles by cells in the draining lymph nodes after hock injection}

The antibody and $\mathrm{T}$ cell responses are influenced by both the presentation of antigen onto both MHC class I and II molecules and the uptake of particles by APCs. We then examined the uptake of blend particles by cells in the draining lymph nodes at different times points post hock injection in order to gain insights into the immune responses we observed in vivo (Figure 8a). PLGA particles resulted in the highest uptake of particles compared to blend particles at all time points. For PLGA particles, the peak percentage of particle-positive cells occurred at $9 \mathrm{~d}$ post injection at approximately $2.2 \%$. In contrast, for both blend ratios, there was increasing percentage of particle-positive cells with increasing time, with the highest percentage at approximately $0.5 \% 30 \mathrm{~d}$ post-injection. There were no significant differences in the uptake between 0.2 and 0.5 blend particles. Thus, blend particles are internalized by cells in the draining lymph nodes at lower levels compared to PLGA particles.

We next examined the distribution of particle internalization among DCs (Figure 8b) and B cells (Figure 8c) for each particle type. $24 \mathrm{~h}$ after injection, DCs accounted for 35-45\% of the cells that internalized particles for all blend ratios. After $9 \mathrm{~d}$, DCs comprised only $~ 10 \%$ 
of the cell types that internalized PLGA particles; for both 0.2 and 0.5 blend ratios, the percentage remained 35-50\%. Thus, for blend particles, DCs comprised a higher percentage of cells that internalized particles compared to PLGA at long time points after injection. B cells accounted for about $40 \%$ of the PLGA uptake after $24 \mathrm{~h}$, and declined to $25 \%$ after $9 \mathrm{~d}$ and $30 \mathrm{~d}$. For 0.2 blend particles, B cells comprised approximately $20 \%$ of the uptake after $24 \mathrm{~h}$ and $9 \mathrm{~d}$; after $30 \mathrm{~d}$, the percentage increased to about $28 \%$. For 0.5 blend particles, B cells comprised $10 \%$ of the uptake after $24 \mathrm{~h}$, increased to about $20 \%$ after $9 \mathrm{~d}$, and decreased to $15 \%$ after $30 \mathrm{~d}$.

We finally examined the average uptake by DCs and B cells for each particle type (Figure $8 \mathrm{~d}$, e). PLGA particles led to the highest uptake by DCs after $24 \mathrm{~h}$ ( 10-fold) and $9 \mathrm{~d}$ ( 2.5fold) compared to blend particles. Thus, although DCs comprised the higher percentage of cell types that internalized blend particles compared to PLGA, the level of internalization of blend particles was lower compared to PLGA particles. After $30 \mathrm{~d}$, the level of uptake by DCs was similar for all particle types. PLGA particles resulted in the highest level of uptake by B cells at all time points compared to blend particles (Figure 8e).

\section{Discussion}

We have developed an antigen delivery platform by blending PLGA and the $\mathrm{pH}$-responsive terpolymer DMAEMA-co-PAA-co-BMA. PLGA has been widely used for the delivery of various biological agents, and products containing PLGA have been approved for human use by the US Food and Drug Administration. ${ }^{[36]}$ The pH-responsive terpolymer, DMAEMAco-PAA-co-BMA, has been shown to mediate cytosolic delivery of peptides ${ }^{[37]}$ and siRNA ${ }^{[25]}$. The terpolymer is inert at neutral $\mathrm{pHs}$ and possesses membrane lytic activity at acidic pHs. ${ }^{[25]}$ We have shown that with increasing terpolymer composition in blend particles, more efficient cross-presentation can be achieved while maintaining class II antigen presentation in vitro (Figure 4). Blend particles also resulted in more sustained release of antigen (Supplemental Figure 2), more robust memory antibody, CD4 ${ }^{+}$and CD8 ${ }^{+}$ $\mathrm{T}$ cell responses in vivo in an composition-dependent manner (Figure 5-7).

The efficiency of both class I and II antigen presentation in vitro was dependent on the blend particle composition: blend particles containing higher terpolymer weight ratios resulted in more effective $\mathrm{CD} 8^{+} \mathrm{T}$ cell stimulation with decreasing $\mathrm{CD} 4^{+} \mathrm{T}$ cell stimulation (Figure 4 ). To our knowledge, utilizing blend polymers to manipulate the intracellular delivery of antigens to class I and II antigen presentation pathways has not been explored. There are several possible mechanisms through which exogenous antigen can be presented onto MHC I (i.e. cross-presentation) for $\mathrm{CD} 8^{+} \mathrm{T}$ cell stimulation. ${ }^{[11,12]}$ In the endosomal pathway, it is not required for antigens to escape into the cytosol for proteasome processing. ${ }^{[38]}$ Instead, the proteases in endosomes process and edit antigens into peptides that can be loaded onto MHC I molecules (through the endoplasmic reticulum associated with the endosomes). In the cytosolic pathway, internalized antigen has to escape into the cytosol for processing by the proteasome and the presentation on MHC I through the endoplasmic reticulum. It is still debatable which pathway will be more efficient for cross presentation. ${ }^{[12,39]}$ 
However, it is clear that systems designed to disrupt endosomal compartments to enable cross presentation should theoretically lead to less class II antigen presentation due to the mass balance of available antigen. Most studies evaluate cross-presentation by endosomaldisruptive systems but have not concurrently analyzed the effect on class II antigen presentation. ${ }^{[21,23]}$ Some technologies, though not clearly addressed, may utilize the endosomal pathway for class I antigen presentation. ${ }^{[22,40]}$ For many of the current $\mathrm{pH}-$ sensitive particulate systems, such as PDEAEMA nanoparticles, ${ }^{[21,29]}$ the size of nanoparticles increases dramatically due to swelling when the $\mathrm{pH}$ is decreased in endosomal/lysosomal compartments; the diameter can increase from $200 \mathrm{~nm}$ to $550 \mathrm{~nm}$ as the $\mathrm{pH}$ decreases from 7 to 6 or lower. ${ }^{[21]}$ This corresponds to an approximately 15 -fold increase in volume and 8-fold increase in surface area, leading to the rupture of endosomes and the escape of nanoparticles (and cargoes) into the cytosolic space. Therefore, in these cases, a small fraction of PDEAEMA nanoparticles were within membrane-bounded vesicles and the majority of them were within the cytosol. These technologies may or may not compromise MHC-II presentation depending on how they manipulate endosomal environments to accomplish processing of proteins for loading on both class I and II molecules. For blend particles, part of antigen was able to escape into cytosolic compartments while part of antigen remained in endosomal/lysosomal compartments together with particles (Figure 3). It is very likely that the blend particle system utilizes both the cytosolic and endosomal pathway for class I presentation, and antigen remained in endosomal/lysosomal compartments was expected to route to class II antigen presentation pathway. We demonstrate that it is possible to tune the composition of the blend particles in order to enhance class I antigen presentation without significantly compromising class II antigen presentation (Figure 4).

Blend particles were able to induce both primary and memory antibody responses. Primary antibody responses mediated by blend particles were low in comparison to Alum, but higher than PLGA. For memory antibody responses, blend particles were able to induce comparable levels to that induced by Alum. This delayed antibody response could be due to two factors: first, the kinetics of antigen release from the blend particles may affect antigen uptake by DCs and B cells that mediate antibody production following prime-boost vaccination. Indeed, the antigen release kinetics from polymeric particles has been shown to affect the levels of memory antibody responses achieved. ${ }^{[41]}$ Though OVA released from both PLGA particles ( 0 blend) and blend particles displayed an initial burst phase followed by the gradual release, blend particles reduced the initial burst phase and yielded a more sustained release profile (Supplemental Figure 2). Thus, blend particles may have enabled slower and more sustained exposure of antigen to B and DC cells, resulting in a weaker primary (measured at only $3 \mathrm{~d}$ post boost vaccination), but robust responses after $60 \mathrm{~d}$ post boost vaccination.

Secondly, the antibody response generated by blend particles were mediated by the cell types that internalize the particles, as well as the level of uptake of antigen and antigenloaded particles. We have also examined the uptake of blend particles by DCs and B cells upon hock injection (Figure 8). Although PLGA particles result in higher overall uptake by both DCs and B cells in the draining lymph nodes (Figure 8d, e), blend particles are superior to PLGA in generating memory antibody responses. This suggests that the higher $\mathrm{CD} 4^{+} \mathrm{T}$ 
cell stimulation mediated by blend particles (Figure 7a, c) perhaps provided greater "help" to stimulate B cells for long-term antibody production. ${ }^{[42-44]}$ Taken together, these results demonstrate that blend particles are able to generate both primary and memory antibody responses better than PLGA particles and comparable to Alum.

Blend particles were able to generate primary $\mathrm{T}$ cell responses in vivo, and that the 0.5 blend particles generated a statistically significant higher level of $\mathrm{CD} 8^{+} \mathrm{T}$ cells in the spleen compared to all other formulations (Figure 7d). Even though blend particles were internalized by DCs in the draining lymph nodes at lower levels compared to PLGA particles (approximately 10-fold lower $24 \mathrm{~h}$ and 2.5 -fold lower $9 \mathrm{~d}$ post-injection) (Figure 8a), comparable or higher levels of $\mathrm{CD} 4^{+}$and $\mathrm{CD} 8^{+} \mathrm{T}$ cell stimulation were achieved. This suggests that blend particles were more effective at $\mathrm{T}$ cell stimulation in vivo, even with lower antigen availability as shown by the lower overall uptake by DCs in the draining lymph nodes (Figure 8d). The low level of uptake of blend particles could partially be attributed to the highly-charged surface of blend particles, which could lead to opsoniziation of particles and internalization by cells at the injection site. ${ }^{[45]}$ Previous studies have shown that the surface passivation of particles with hydrophilic molecules such as poly(ethylene glycol) can enhance particle drainage away from the injection site, in addition to enhancing the uptake by DCs in the draining lymph nodes. ${ }^{[46,47]}$ We expect that surface passivation of the blend particles would have similar effects, further enhancing antigen and particle access by cells in the draining lymph nodes, and thus the level of $\mathrm{T}$ cell stimulation achieved.

The ability to generate memory $\mathrm{T}$ cell populations is an important aspect of effective vaccines. ${ }^{[6,10]}$ Memory $\mathrm{T}$ cells can quickly respond to infections due to their high frequencies, rapid acquisition of effector functions, and the ability to home to the site of infections. Blend particles, in particular 0.5 blend particles, exhibited superior ability of maintaining both $\mathrm{CD} 4^{+}$and $\mathrm{CD} 8^{+} \mathrm{T}$ cell responses in comparison to PLGA and Alum. The generation of antigen-specific $\mathrm{CD} 4^{+} \mathrm{T}$ cells is critical in the generation memory $\mathrm{CD} 8^{+} \mathrm{T}$ cell populations. ${ }^{[6,8,48]}$ It has been shown that antigen-specific $\mathrm{CD}^{+} \mathrm{T}$ cell help in the primary phase is a requirement for the generation of memory $\mathrm{CD} 8^{+} \mathrm{T}$ cells that can expand upon reencounter with antigen. ${ }^{[8,49]}$ Although blend particles generated comparable levels of CD4 ${ }^{+}$ $\mathrm{T}$ cells in the primary phase compared to PLGA and Alum, they generated higher levels of memory $\mathrm{CD} 4^{+}$and $\mathrm{CD} 8^{+} \mathrm{T}$ cells. We also examined the phenotype of memory $\mathrm{CD} 8^{+} \mathrm{T}$ cells mediated by particles using tetramer staining (Supplemental Figure 4). Consistent with intracellular IFN $\gamma$ staining, blend particles resulted in a higher population of antigenspecific CD8 ${ }^{+} \mathrm{T}$ cells compared to PLGA particles (Supplemental Figure 4a). For blend particles, approximately $40 \%$ of the antigen-specific $\mathrm{T}$ cells were central memory $\mathrm{T}$ cells $\left(\mathrm{T}_{\mathrm{CM}}\right)$ and $54 \%$ were effector memory $\mathrm{T}$ cells $\left(\mathrm{T}_{\mathrm{EM}}\right)$ (Supplemental Figure $4 \mathrm{~b}$ ). In contrast, for PLGA particles, only $24 \%$ of antigen-specific $\mathrm{T}$ cells were $\mathrm{T}_{\mathrm{CM}}$, while $70 \%$ were $\mathrm{T}_{\mathrm{EM}}$. $\mathrm{T}_{\mathrm{EM}}$ possess effector functions and migrate to inflammed peripheral tissue, while $\mathrm{T}_{\mathrm{cm}}$ home to $\mathrm{T}$ cell areas of secondary lymphoid organs, and readily proliferate and differentiate into effector cells upon antigen stimulation. ${ }^{[50]}$ It has been shown that $\mathrm{T}_{\mathrm{CM}}$ cells confer superior antimicrobial and antitumoral immunity compared to $\mathrm{T}_{\mathrm{EM}} \cdot{ }^{[51,52]}$ Thus, not only do blend particles result in high levels of antigen-specific $\mathrm{T}$ cells, but they also create a pool of central memory $\mathrm{T}$ cells that can rapidly respond to future pathogenic challenges. This suggests that 
the quality of the $\mathrm{CD} 4^{+} \mathrm{T}$ cell help in the primary phase mediated by blend particles is higher than PLGA particles, leading to a larger pool of memory $\mathrm{CD} 8^{+} \mathrm{T}$ cells that potentially respond more effectively after antigen re-encounter.

We would like to note blend particles are able to generate and maintain robust antibody and $\mathrm{T}$ cell responses in the absence of immune-modulators such as toll-like receptor agonists, which can provide co-stimulatory and soluble signals that can further augment and enhance primary and memory immune responses. ${ }^{[53]}$ We expect that the blend particle platform can readily incorporate such molecules. We performed preliminary experiments with blend particles incorporating a clinically relevant antigen, herpes simplex virus- 2 antigen $\mathrm{gD}$ and the toll-like receptor 9 agonist, $\mathrm{CpG}$ ODNs (Supplemental Figure 5). We were able to achieve a much signficantly higher level of $\mathrm{CD} 4^{+}$and $\mathrm{CD} 8^{+} \mathrm{T}$ cell responses compared to Alum.

In summary, blend particles permits the ease of tuning the composition of polymers to achieve desirable release of protein and antigen presentation and incorporation of immunostimulatory agents. They serve as a versatile and modular vaccine delivery platform for the generation of robust antibody and $\mathrm{T}$ cell responses against a variety of infectious diseases.

\section{Conclusion}

In this report we developed a novel particulate delivery platform using polymer blends. Careful selection of polymer blends and the fabrication process allowed the composition of particles to be finely tuned. In addition, polymer blends allow the selection of polymers from a library of polymers tested in clinical applications. Here, we demonstrated that this platform was able to route antigen effectively to both the class I and class II antigen presentation pathways in vitro than using one polymer alone, i.e. PLGA. In comparison with PLGA particles, though the uptake of blend particles of the current formulation by antigen presenting cells in vivo was significantly lower, the memory antibody and T cell immune responses in vivo were surprisingly higher. Future work can be focused on optimizing the composition and surface chemistry of blend particles to enhance cellular uptake in vivo.

\section{Experimental Section}

\section{Cell culture}

A DC line, DC2.4, ${ }^{[54]}$ (a gift from K.L. Rock, University of Massachusetts Medical School) and the B3Z T cell hybridoma (a gift from N. Shastri, University of California, Berkeley) were maintained as described previously. ${ }^{[55]} \mathrm{B} 3 \mathrm{Z}$ T cells were engineered to secrete $\beta$ galactosidase when its T-cell receptor recognizes $\mathrm{OVA}_{257-264}$ (SIINFEKL) presented on the murine $\mathrm{H}-2 \mathrm{k}^{\mathrm{b}} \mathrm{MHC}$ class I molecule. The DO11.10 T cell hybridoma. ${ }^{[56]}$ (a gift from D.M. Underhill, University of Washington), which recognizes OVA $323-339$ (ISQAVHAAHAEINEAGR) presented on the murine I-A ${ }^{\mathrm{d}}$ MHC class II molecule, and the $\mathrm{BC} 1$ mouse spleen DC cell line were maintained as previously described. ${ }^{[57]}$ 


\section{Chemicals}

Dimethylaminoethyl methacrylate (DMAEMA) (Sigma-Aldrich, St. Louis, MO) and butyl methacrylate (BMA) (Sigma-Aldrich, St. Louis, MO) were distilled under reduced pressure. Tetrahydrofuran (THF) and 2,2' -Azobisisobutyronitrile (AIBN) (Sigma-Aldrich, St. Louis, MO) were used as received. Other chemicals were of reagent grade and used without further purification.

\section{Synthesis of 2-Propylacrylic acid}

2-Propylacrylic acid (PAA) was synthesized based on a previous report by Ferritto and Tirell. ${ }^{[58]}$ Briefly, diethyl propylmalonate $(0.0455 \mathrm{~mol})$ was added to $\mathrm{KOH}(1 \mathrm{M})$ in $95 \%$ enthanol. The solution was allowed to stir for overnight at room temperature. After acidification with $\mathrm{HCl}(1 \mathrm{M})$ to $\mathrm{pH} 2$, the solution was extracted three times by diethyl ether. Then the crude product was cooled to $-4{ }^{\circ} \mathrm{C}$ prior to the addition of diethylamine $(3.2 \mathrm{~g})$ and formaldehyde solution $(3.54 \mathrm{~g})$. The solution was allowed to warm to room temperature and stirred for $24 \mathrm{~h}$, followed by another $8 \mathrm{~h}$ stirring at $60^{\circ} \mathrm{C}$ with reflux. After cooling the mixture to $0{ }^{\circ} \mathrm{C}$, concentrated sulfuric acid was added drop-wise and diethyl ether was utilized to extract product. The crude product from the last step was then hydrolyzed by $\mathrm{KOH}(1 \mathrm{M})$ aqueous solution at $85^{\circ} \mathrm{C}$ for $20 \mathrm{~h}$ with reflux. After acidification, the crude PAA was extracted by diethyl ether and vacuum-distillated. Nuclear magnetic resonance (NMR) spectroscopy (500 MHz ${ }^{1} \mathrm{H}$ Bruker spectrometers) was used to determine the PAA product.

\section{Synthesis of DMAEMA-co-PAA-co-BMA terpolymer}

The radical polymerization of the random DMAEMA-co-PAA-co-BMA terpolymers was adapted from a protocol as previously described. ${ }^{[26]}$ Briefly, the reaction mixtures of monomers (PAA:DMAEMA:BMA 1:1:2 mol ratio) and AIBN $(2 \mathrm{mM})$ in THF (monomers:THF 1:3 mass ratio) were purged with nitrogen for $1 \mathrm{~h}$, and polymerization was carried out at $60^{\circ} \mathrm{C}$ for $15 \mathrm{~h}$. The reaction solution was then added drop-wise to an excess mixture of cold diethylether/pentane to precipitate the terpolymer. The white precipitate was re-dissolved in acetone $(2 \mathrm{ml})$ and then added drop-wise to an excess of cold pentane. The precipitation in pentane was then repeated once. Upon lyophilization, polymers were successfully obtained as a clear and off-white pellet.

\section{Molecular Weight and Composition of the terpolymer}

The molecular weight of the terpolymer was determined by gel permeation chromatography (Viscotek, Malvern) using chloroform as the solvent phase. Weight average molecular weight and number average molecular weight were calculated in reference to poly(methyl methacrylate) standards. The compositions of the terpolymers were determined by proton nuclear magnetic resonance spectroscopy in $\mathrm{CDCl}_{3}$.

\section{Fabrication of blend particles}

A blend of PLGA (50:50 lactide:glycolide, MW 20,000 g/mol) and DMAEMA-co-PAAco-BMA (20:30:50 DMAEMA:PAA:BMA, MW $\sim 22 \mathrm{kDa}$, PDI $\sim 1.2$ ) was used to fabricate particles using the double emulsion solvent evaporation method. Briefly, ovalbumin (OVA grade VII, Sigma) solution $(100 \mu \mathrm{l}, 10 \mathrm{mg} / \mathrm{ml})$ was added to a polymer solution $(1 \mathrm{ml}, 50$ 
$\mathrm{mg} / \mathrm{ml}$ ) containing varying weight fractions of DMAEMA-co-PAA-co-BMA to the total polymer weight in dichloromethane. The solution was sonicated with a Branson Sonifier 450 for $10 \mathrm{sec}$ at constant duty cycle (20\% maximum output). An oil-in-water emulsion was formed by adding polyvinyl alcohol (PVA) $(2 \mathrm{ml}, 50 \mathrm{mg} / \mathrm{ml})$ drop-wise to the organic phase while vortexing. This emulsion was sonicated for $10 \mathrm{sec}$ and then poured into PVA (4 ml, 50 $\mathrm{mg} / \mathrm{ml}$ ) while vortexing. Finally, the emulsion was poured into $4 \mathrm{ml}$ of $0.06 \%$ PVA (4 ml, $0.6 \mathrm{mg} / \mathrm{ml}$ ) in a beaker. The resulting particle suspension was stirred for $4 \mathrm{~h}$ at room temperature. Particles were washed by centrifugation (12000 rpm for 15 mins) three times with MilliQ water. After each centrifugation, particles were vigorously vortexed to completely resuspend the particles. The level of protein incorporated in particles was characterized by solubilizing and heating a known amount of particles in a $0.1 \mathrm{~N}$ sodium hydroxide $/ 1 \%$ sodium dodecyl sulfate solution at $95^{\circ} \mathrm{C}$. The concentration of protein was quantified using the bicinchoninic acid (BCA) protein assay.

\section{Characterization of blend particles by scanning electron microscope (SEM) and dynamic light scattering (DLS)}

SEM was used to characterize the size and morphology of blend particles. SEM samples were prepared by spin-coating a particle solution onto a piece of silicon wafer and dried overnight. The samples were sputter-coated with $10 \mathrm{~nm}$ of platinum using a Gatan Precision Etching and Coating System (Pleasanton, CA). Samples were analyzed with a JEOL 7000 SEM with a beam voltage of $5 \mathrm{kV}$ (Electron Microscopy Center, University of Washington).

The size, polydispersity and zeta potential of blend particles were measured by DLS method using Malvern ZetaSizer Nano. Particles were re-suspended in a $\mathrm{KNO}_{3}$ solution (10 mM) for all measurements.

\section{Co-delivery of blend particles with calcein to DC2.4}

DC2.4 cells were plated at $1.5 \times 10^{5}$ cells per well on $12 \mathrm{~mm}$-coverslips in 24 -well polystyrene plates and incubated at $37^{\circ} \mathrm{C}$ overnight. Blend particles were fabricated with HiLyte647-labeled PLGA to fluorescently image particles. Blend particles were added at a concentration of $50 \mu \mathrm{g} / \mathrm{ml}$ together with calcein $(0.2 \mathrm{mg} / \mathrm{ml})$ and then incubated for $4 \mathrm{~h}$ at $37^{\circ} \mathrm{C}$. Dark-red, carboxylated polystyrene particles $(200 \mathrm{~nm}$, Life Technologies, NY) were used as controls. Cells were washed and fixed with paraformaldehyde (4\%) in DPBS for 20 min at room temperature. The coverslips were then washed and mounted onto glass coverslips with hard-set mounting medium with 4',6-diamidino-2-phenylindole (DAPI) (Vector Laboratories Inc., CA). Confocal microscope was utilized for acquisition of images from different z-stacks (63 × oil-immersion objective, LSM 510 Meta, Zeiss). ImageJ was used to analyze the images.

\section{Fluorescent microscopy analysis of blend particles in endosomal/lysosomal compartments or the cytosol}

The intracellular trafficking of fluorescently labeled blend particles containing OVA-FITC and quantum dots was examined using immunofluorescence microscopy. Briefly, DC2.4 cells were plated on round coverslips in 24-well plates and incubated overnight. Blend particles, equivalent to $0.125 \mu \mathrm{g} / \mathrm{ml}$ of OVA-FITC, were incubated with cells for $4 \mathrm{~h}$ and then 
washed. Cells were then fixed and permeabilized with the Cytofix/Cytoperm Kit following the manufacturer's protocol (BD Biosciences). Cells were then incubated with rabbit polyclonal antibody against EEA-1 $(10 \mu \mathrm{g} / \mathrm{ml})$, an early endosomal marker, and rat polyclonal antibody against LAMP-2 $(10 \mu \mathrm{g} / \mathrm{ml})$, a lysosomal marker, on ice for $1 \mathrm{~h}$. Cells were washed three times and then incubated with Cy3-labeled anti-rabbit IgG $(5 \mu \mathrm{g} / \mathrm{ml})$ and AlexaFluor647 anti-rat IgG $(5 \mu \mathrm{g} / \mathrm{ml})$ on ice for $1 \mathrm{~h}$. Cells were then washed three times, mounted on a microscope slide with VectaShield mounting solution containing DAPI, and examined with a Leica SP1 confocal microscope.

Images were analyzed using the ImageJ software. Images were converted into 8-bit files and the average background intensity was determined. Binary images were created by assigning pixels that had an intensity three standard deviations above the background intensity as 1 ; pixels with intensities lower than the threshold value was set to 0 . Binary images from the different fluorescent channels were then assigned a RGB color and then overlaid.

\section{In vitro antigen presentation assays}

DC2.4 or BC-1 cells were seeded in triplicates at a density of $5 \times 10^{4}$ per well in 96-well round-bottom plates and incubated overnight. Cells were loaded with blend particles containing varying doses of OVA and incubated with cells for $4 \mathrm{~h}$. Cells were then washed three times with PBS and co-incubated with $1 \times 10^{5} \mathrm{~B} 3 \mathrm{Z}^{[55]}$ or DO11.10-GFP ${ }^{[56]} \mathrm{T}$ cell hybridomas for $20-24 \mathrm{~h}$ in culture media $(200 \mu \mathrm{l})$. The activation of B3Z and DO11.10-GFP $\mathrm{T}$ cells were determined by the level of $\beta$-galactosidase activity and IL-2 secretion, respectively.

\section{Animals and immunization}

6-8 week old female C57BL/6 mice were obtained from The Jackson Laboratory (Bar Harbor, Maine). Groups of mice ( $\mathrm{n}=4$ mice/group) were immunized with blend particles loaded with OVA $(20 \mu \mathrm{g})$ via hock administration at weeks 0 and 2 . For adjuvant groups, OVA $(0.4 \mathrm{mg} / \mathrm{ml})$ in DPBS was mixed with $2 \%$ of Alhydrogel at 1:1 volume ratio following the manufacturer's protocol. At the indicated time points, mice were put under anesthesia, and serum was collected through retro-orbital bleeding. Mice were then sacrificed and the spleen and draining lymph nodes were harvested for assessment of primary $\mathrm{T}$ cell responses at $3 \mathrm{~d}$ post-boost and memory $\mathrm{T}$ cell responses $60 \mathrm{~d}$ post-boost. All procedures used in this study complied with federal guidelines and institutional policies, and were approved by the University of Washington Institutional Care and Animal Use Committee.

\section{Enzyme-linked immunosorbent assay (ELISA)}

For the detection of OVA-specific antibodies in the serum, high-binding ELISA plates (Maxisorp) were coated with OVA protein $(200 \mu \mathrm{g} / \mathrm{ml}, 100 \mu \mathrm{l})$ in carbonate buffer $(\mathrm{pH}=$ 9.6) overnight at $4{ }^{\circ} \mathrm{C}$. Plates were then washed three times with $0.1 \%$ Tween-20 in PBS and blocked with 1\% FBS in PBS (blocking buffer) for $3 \mathrm{~h}$ at room temperature. Plates were then washed two times. Samples were diluted serially in blocking buffer, added to plates, and incubated for $1 \mathrm{~h}$ at room temperature. Plates were washed 7-8 times and then incubated with HRP-conjugated rabbit anti-mouse IgG antibody (1:10000, Sigma-Aldrich) for $20 \mathrm{~min}$ at room temperature. Plates were washed 7-8 times and then developed colorimetrically 
with tetramethylbenzidine (TMB) substrate. The absorbance at $450 \mathrm{~nm}$ was measured using SpectraMax M5 microplate reader (Molecular Devices; Sunnyvale, CA). Titers represent the highest dilution of samples showing a two-fold $\mathrm{OD}_{450}$ value over background controls.

Samples were performed in duplicates.

\section{Preparation of single cell suspension from spleens and lymph nodes}

Spleens, iliac, and inguinal lymph nodes were collected and resuspended in RPMI 1640 (0.5 $\mathrm{ml}$ ) supplemented with $10 \% \mathrm{FBS}, 1 \%$ penicillin/streptomycin, $2 \mathrm{mM} \mathrm{L-glutamine,} \mathrm{and} 1$ $\mathrm{mM}$ sodium pyruvate (complete media). Spleens were minced into small pieces. Tissues were incubated with collagenase $\mathrm{D}(1.8 \mathrm{mg} / \mathrm{ml})$ and DNase $(30 \mu \mathrm{g} / \mathrm{ml})$ at $37^{\circ} \mathrm{C}$ for $30 \mathrm{~min}$. Tissues were centrifuged, the solutions discarded, and then re-suspended in Hank's Balance Salt Solution (HBSS) containing EDTA ( $5 \mathrm{mM}$ ) and $1 \% \mathrm{FBS}$ for $5 \mathrm{~min}$ at $37^{\circ} \mathrm{C}$. A single cell suspension was obtained by grinding the tissues through a $70 \mu \mathrm{m}$ cell strainer. For spleen cells, cells were incubated with ACK lysis buffer $\left(0.15 \mathrm{M} \mathrm{NH}_{4} \mathrm{Cl}, 1 \mathrm{M} \mathrm{KHCO}_{3}\right.$, and $0.1 \mathrm{mM} \mathrm{Na}_{2}$ EDTA, pH 7.4) to lyse red blood cells. Cells were washed, resuspended in complete media and counted.

\section{Measurement of antigen-specific $\mathrm{CD}^{+}$and $\mathrm{CD} 8^{+} \mathrm{T}$ cells}

$2 \times 10^{6}$ spleen or lymph node cells were plated in 96-well plates with media containing either the class I OVA peptide $\left(\mathrm{OVA}_{257-264}\right)(2 \mu \mathrm{M})$ or the class II OVA peptide $\left(\mathrm{OVA}_{323-339}\right)(10 \mu \mathrm{M})$ for $2 \mathrm{~h}$ at $37^{\circ} \mathrm{C}$ to measure antigen-specific $\mathrm{CD} 8^{+}$or $\mathrm{CD} 4^{+} \mathrm{T}$ cells, respectively. Media $(100 \mu \mathrm{l})$ containing GolgiPlug/GolgiStop (BD Biosciences) was then added and cells were incubated for an additional $4 \mathrm{~h}$. Cells were then washed with DPBS and then stained with the fixable viability dye eFluor 780 following the manufacturer's protocol (eBiosciences). The cells were washed and incubated with anti-CD16/CD32 antibody to block Fc receptors, and stained with PerCp-Cy5.5 anti-mouse CD4 (clone RM4-5), FITC anti-mouse CD8 (clone 53-6.7) and APC anti-mouse CD3 (clone 145-2C11) antibodies for $20 \mathrm{~min}$ at $4{ }^{\circ} \mathrm{C}$. After fixation and membrane penetration with Cytofix/ Cytoperm (BD Biosciences), cells were incubated with PE anti-mouse intracellular IFN- $\gamma$ antibody (clone XMG1.2) for $30 \mathrm{~min}$ at $4{ }^{\circ} \mathrm{C}$. Cells were washed three times, resuspended in FACS buffer and analyzed by flow cytometry on a BD LSRII flow cytometer.

\section{Measurement of particle internalization by cells in the draining lymph nodes}

Blend particles were fabricated as above but with HiLyte647-labeled PLGA to fluorescently track particles. $0.5 \mathrm{mg}$ of particles / mouse were administered via hock injection. At the indicated time points, the draining lymph nodes were harvested and a single-cell suspension obtained. Cells were stained with eFluor e450 anti-CD11c, PerCp-Cy5.5 anti-F4/80, PE-Cy7 anti-B220, FITC anti-CD3, and PE anti-DEC205 and analyzed with a BD LSRII flow cytometer.

\section{Statistical analysis}

All the experiments were repeated two to three times independently as indicated in Figure legends. Student t-test was used to compare the difference between experimental groups. $\mathrm{p}<$ 0.05 was considered as statistically different. 


\section{Supplementary Material}

Refer to Web version on PubMed Central for supplementary material.

\section{Acknowledgments}

We thank the Cell Analysis Facility in the Department of Immunology, the Keck Microscopy Facility, and the UW Electron Microscopy Center. Partial support for this study was funded by AI088597 to H.S. from the National Institute of Allergy and Infectious Diseases (NIAID), the Office of Research on Women's Health (ORWH). The content is solely the responsibility of the authors and does not necessarily represent the official views of NIAID, ORWH or NIH.

\section{References}

1. Rappuoli R. Nat Med. 2004; 10:1177-1185. [PubMed: 15516917]

2. Richie TL, Saul A. Nature. 2002; 415:694-701. [PubMed: 11832958]

3. Finn OJ. Nat Rev Immunol. 2003; 3:630-641. [PubMed: 12974478]

4. Banchereau J, Briere F, Caux C, Davoust J, Lebecque S, Liu YT, Pulendran B, Palucka K. Annu Rev Immunol. 2000; 18:767-811. [PubMed: 10837075]

5. Guermonprez P, Valladeau J, Zitvogel L, Thery C, Amigorena S. Annu Rev Immunol. 2002; 20:621-667. [PubMed: 11861614]

6. Williams MA, Bevan MJ. Annu Rev Immunol. 2007; 25:171-192. [PubMed: 17129182]

7. Constant SL, Bottomly K. Annu Rev Immunol. 1997; 15:297-322. [PubMed: 9143690]

8. Shedlock DJ, Shen H. Science. 2003; 300:337-337. [PubMed: 12690201]

9. Bishop GA, Haxhinasto SA, Stunz LL, Hostager BS. Crit Rev Immunol. 2003; 23:149-197. [PubMed: 14584878]

10. Sallusto F, Lanzavecchia A, Araki K, Ahmed R. Immunity. 2010; 33:451-463. [PubMed: 21029957]

11. Ackerman AL, Cresswell P. Nat Immunol. 2004; 5:678-684. [PubMed: 15224093]

12. Amigorena S, Savina A. Curr Opin Immunol. 2010; 22:109-117. [PubMed: 20171863]

13. Trombetta ES, Mellman I. Annu Rev Immunol. 2005; 23:975-1028. [PubMed: 15771591]

14. Villadangos JA, Schnorrer P, Wilson NS. Immunol Rev. 2005; 207:191-205. [PubMed: 16181337]

15. Burgdorf S, Kautz A, Bohnert V, Knolle PA, Kurts C. Science. 2007; 316:612-616. [PubMed: 17463291]

16. Falo LD, Kovacsovicsbankowski M, Thompson K, Rock KL. Nat Med. 1995; 1:649-653. [PubMed: 7585145]

17. Kovacsovicsbankowski M, Clark K, Benacerraf B, Rock KL. Proc Natl Acad Sci U S A. 1993; 90:4942-4946. [PubMed: 8506338]

18. Oh YK, Harding CV, Swanson JA. Vaccine. 1997; 15:511-518. [PubMed: 9160518]

19. Wick MJ, Pfeifer JD. Eur J Immunol. 1996; 26:2790-2799. [PubMed: 8921970]

20. Reddy ST, Swartz MA, Hubbell JA. Trends Immunol. 2006; 27:573-579. [PubMed: 17049307]

21. Hu Y, Litwin T, Nagaraja AR, Kwong B, Katz J, Watson N, Irvine DJ. Nano Letters. 2007; 7:3056-3064. [PubMed: 17887715]

22. Hirosue S, Kourtis IC, van der Vlies AJ, Hubbell JA, Swartz MA. Vaccine. 2010; 28:7897-7906. [PubMed: 20934457]

23. Flanary S, Hoffman AS, Stayton PS. Bioconj Chem. 2009; 20:241-248.

24. Panyam J, Labhasetwar V. Advanced drug delivery reviews. 2003; 55:329-347. [PubMed: 12628320]

25. Convertine A, Benoit D, Duvall C, Hoffman A, Stayton P. J Controlled Release. 2009; 133:221229.

26. Takeda N, Nakamura E, Yokoyama M, Okano T. J Controlled Release. 2004; 95:343-355.

27. Kurisawa M, Yokoyama M, Okano T. J Controlled Release. 2000; 68:1-8. 
28. Murthy N, Robichaud JR, Tirrell DA, Stayton PS, Hoffman AS. J Controlled Release. 1999; 61:137-143.

29. van de Wetering P, Moret EE, Schuurmans-Nieuwenbroek NME, van Steenbergen MJ, Hennink WE. Bioconj Chem. 1999; 10:589-597.

30. El-Sayed, SJGMEH. Biologically-Responsive Hybrid Biomaterials. World Scientific Publishing; Singapore: 2010.

31. Fu K, Harrell R, Zinski K, Um C, Jaklenec A, Frazier J, Lotan N, Burke P, Klibanov AM, Langer R. J Pharm Sci. 2003; 92:1582-1591. [PubMed: 12884245]

32. Allison SD. Expert Opinion on Drug Delivery. 2008; 5:615-628. [PubMed: 18532918]

33. Joshi VB, Geary SM, Salem AK. Aaps Journal. 2013; 15:85-94. [PubMed: 23054976]

34. Banchereau J, Steinman RM. Nature. 1998; 392:245-252. [PubMed: 9521319]

35. Gupta RK. Adv Drug Del Rev. 1998; 32:155-172.

36. Jain RA. Biomaterials. 2000; 21:2475-2490. [PubMed: 11055295]

37. Duvall CL, Convertine AJ, Benoit DSW, Hoffman AS, Stayton PS. Mol Pharm. 2010; 7:468-476. [PubMed: 19968323]

38. Ackerman AL, Kyritsis C, Tampe R, Cresswell P. Proc Natl Acad Sci U S A. 2003; 100:12889_ 12894. [PubMed: 14561893]

39. Vyas JM, Van der Veen AG, Ploegh HL. Nat Rev Immunol. 2008; 8:607-618. [PubMed: 18641646]

40. Broaders KE, Cohen JA, Beaudette TT, Bachelder EM, Frechet JMJ. Proc Natl Acad Sci U S A. 2009; 106:5497-5502. [PubMed: 19321415]

41. Kanchan V, Katare YK, Panda AK. Biomaterials. 2009; 30:4763-4776. [PubMed: 19540583]

42. Parker DC. Annu Rev Immunol. 1993; 11:331-360. [PubMed: 8476565]

43. Smith KM, Pottage L, Thomas ER, Leishman AJ, Doig TN, Xu DM, Liew FY, Garside P. J Immunol. 2000; 165:3136-3144. [PubMed: 10975827]

44. McHeyzer-Williams M, Okitsu S, Wang N, McHeyzer-Williams L. Nat Rev Immunol. 2012; 12:24-34. [PubMed: 22158414]

45. Owens DE, Peppas NA. International Journal of Pharmaceutics. 2006; 307:93-102. [PubMed: 16303268]

46. Moghimi SM. Biomaterials. 2006; 27:136-144. [PubMed: 16019063]

47. Zhan X, Tran KK, Shen H. Mol Pharm. 2012; 9:3442-3451. [PubMed: 23098233]

48. Ahmed R, Bevan MJ, Reiner SL, Fearon DT. Nat Rev Immunol. 2009; 9:662-668. [PubMed: 19680250]

49. Janssen EM, Lemmens EE, Wolfe T, Christen U, von Herrath MG, Schoenberger SP. NATURE. 2003; 421:852-856. [PubMed: 12594515]

50. Sallusto F, Geginat J, Lanzavecchia A. Annu Rev Immunol. 2004; 22:745-763. [PubMed: 15032595]

51. Wherry EJ, Teichgraber V, Becker TC, Masopust D, Kaech SM, Antia R, von Andrian UH, Ahmed R. Nat Immunol. 2003; 4:225-234. [PubMed: 12563257]

52. Klebanoff CA, Gattinoni L, Torabi-Parizi P, Kerstann K, Cardones AR, Finkelstein SE, Palmer DC, Antony PA, Hwang ST, Rosenberg SA, Waldmann TA, Restifo NP. Proc Natl Acad Sci U S A. 2005; 102:9571-9576. [PubMed: 15980149]

53. Iwasaki A, Medzhitov R. Nat Immunol. 2004; 5:987-995. [PubMed: 15454922]

54. Shen ZH, Reznikoff G, Dranoff G, Rock KL. J Immunol. 1997; 158:2723-2730. [PubMed: 9058806]

55. Shastri N, Gonzalez F. J Immunol. 1993; 150:2724-2736. [PubMed: 8454852]

56. Underhill DM, Bassetti M, Rudensky A, Aderem A. J Exp Med. 1999; 190:1909-1914. [PubMed: 10601366]

57. Yanagawa Y, Iijima N, Iwabuchi K, Onoe K. J Leukocyte Biol. 2002; 71:125-132. [PubMed: 11781388]

58. Ferrito MT, DA. Macromol Syn. 1992; 11:59-62. 


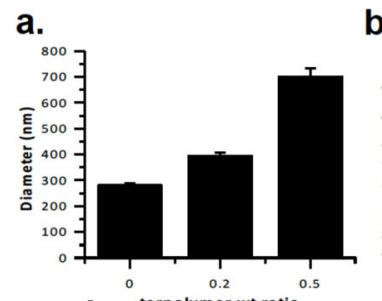

b.

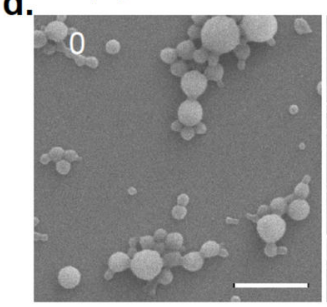

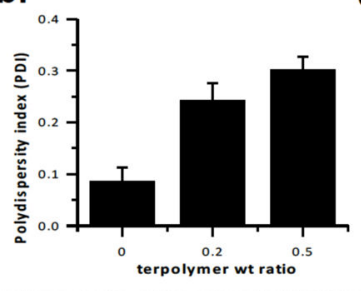

c.

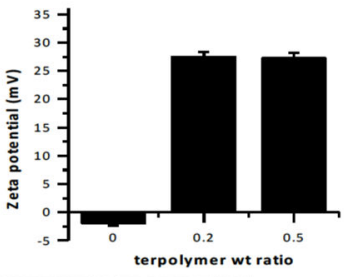

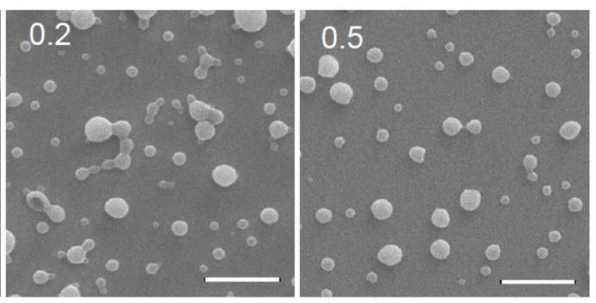

Figure 1.

Characterization of blend particles. $\mathbf{a}$, Size, $\mathbf{b}$, polydispersity, and $\mathbf{c}$, zeta potential of blend particles determined by dynamic light scattering (DLS). Size and zeta potential of blend particles were measured in a $10 \mathrm{mM} \mathrm{KNO}_{3}$ solution with a pH of 6.0. Values are the mean size or zeta potential of particles from three independent batches \pm s.e. d, Representative SEM micrographs of the blend particles containing 0, 0.2, and 0.5 weight fraction of DMAEMA-PAA-BMA terpolymer, respectively. Scale bar = $1 \mu \mathrm{m}$. 


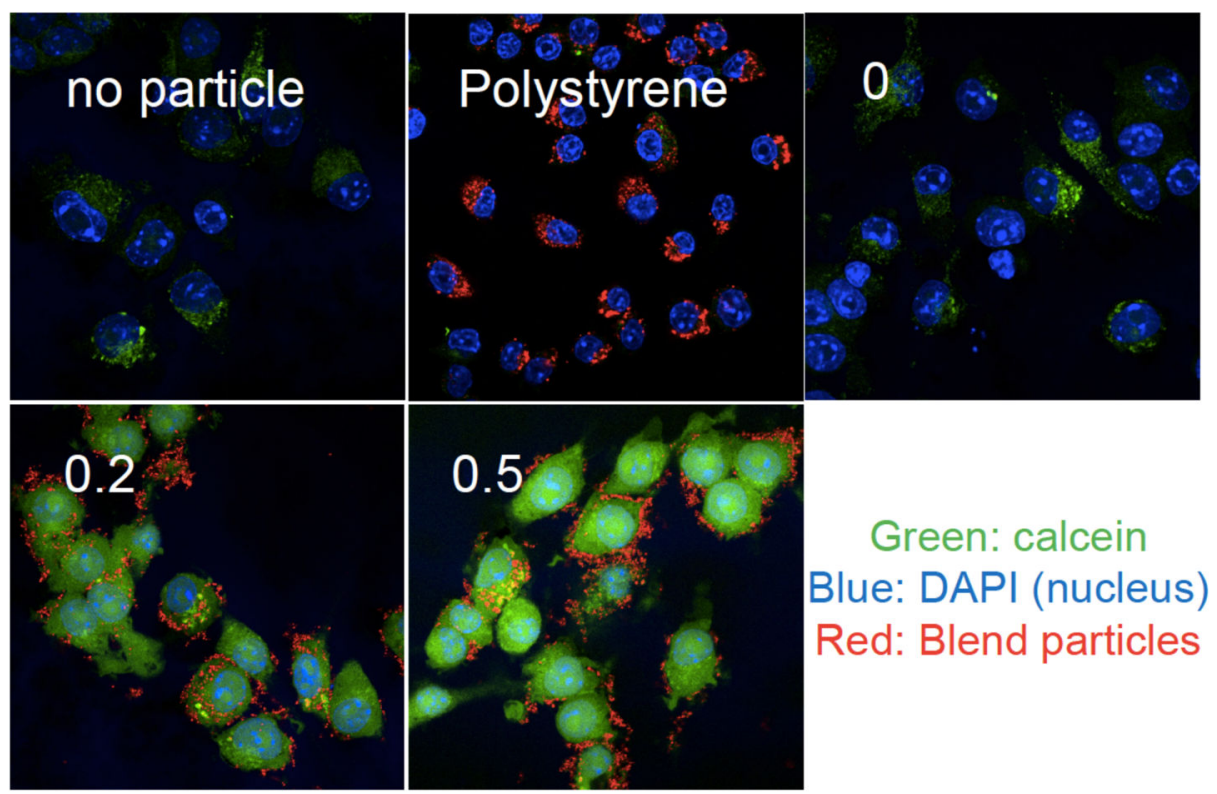

Figure 2.

Intracellular distribution of calcein in DCs co-delivered with blend particles. $200 \mathrm{~nm}$ polystyrene (PS) particles, PLGA particles (0), blend particles have weight ratio as 0.2 and $0.5(0.2,0.5)$. Cells were co-incubated with the membrane impermeable dye, calcein and the indicated particles at $37^{\circ} \mathrm{C}$ for $4 \mathrm{~h}$. Blue: nucleus, green: calcein, red: cell membrane. Scale bar $=10 \mu \mathrm{m}$. The images are representative of two independent experiments. Three to five regions for each sample were taken. 

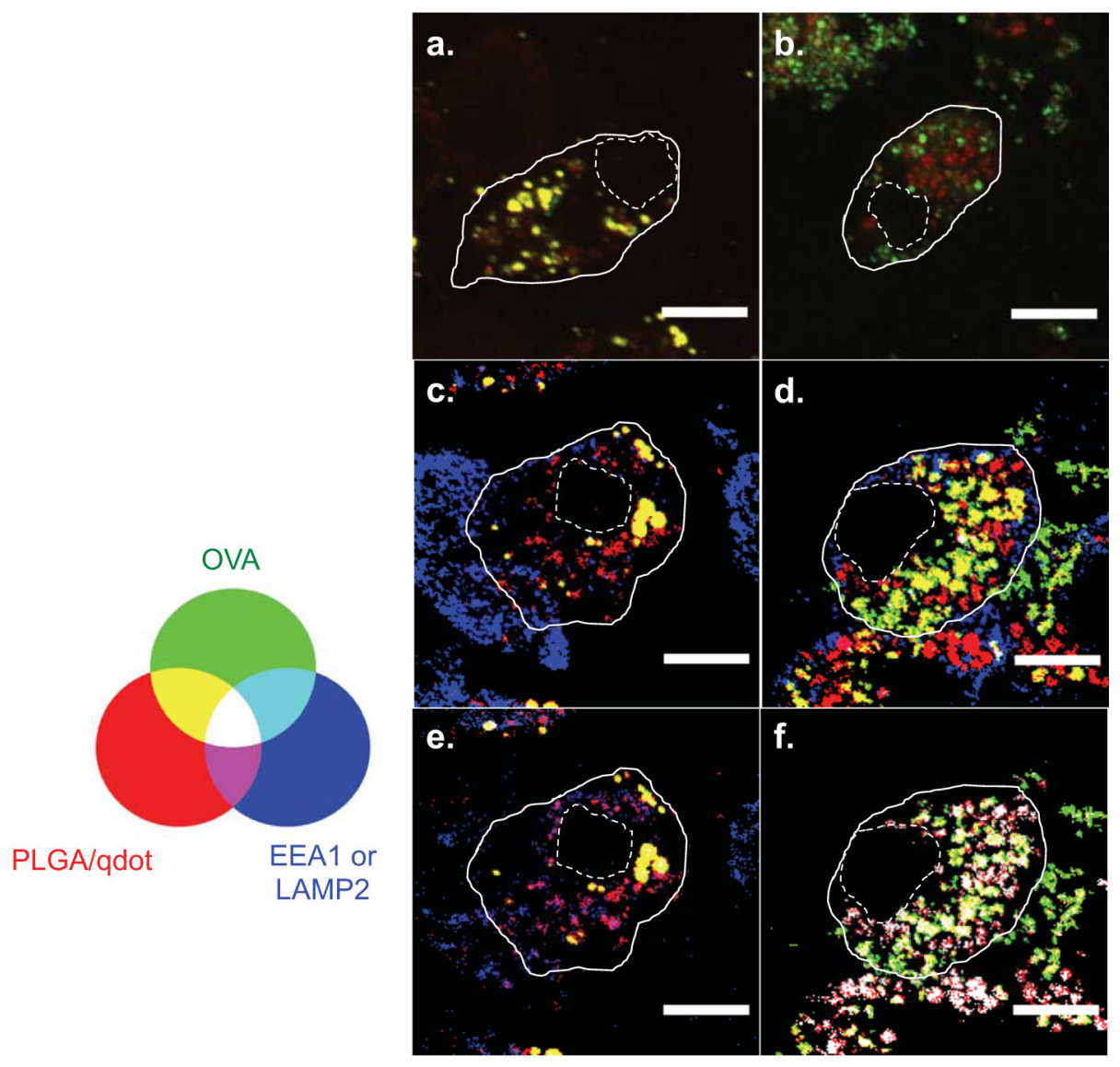

Figure 3.

The intracellular distribution of protein encapsulated in particles. PLGA (a, c, e) and 0.5 blend (b, d, f) particles were loaded with quantum dots (red) and OVA-FITC (green) and incubated with DCs at $37^{\circ} \mathrm{C}$ for $4 \mathrm{~h}$. Cells were stained for early endosomal antigen 1 (EEA-1) (c, d) and LAMP-2 (g, h) to distinguish early endosomes and late endosomes/lysosomes, respectively. Images c-f were obtained by converting original images into binary images. The average background intensity was determined and binary images were created by assigning pixels that had an intensity three standard deviations above the background intensity as 1 ; pixels with intensities lower than the threshold value was set to 0 . Binary images from the different fluorescent channels were then assigned a RGB color and overlaid. Scale bar $=10 \mu \mathrm{m}$. Based on the transmitted images, the cell membrane is outlined by a solid line and the nucleus is shown in a dotted outline. The images are representative of two independent experiments. Three to five regions for each sample were taken. 
a.

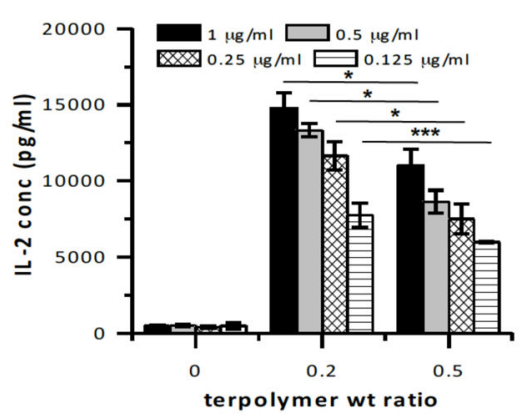

b.

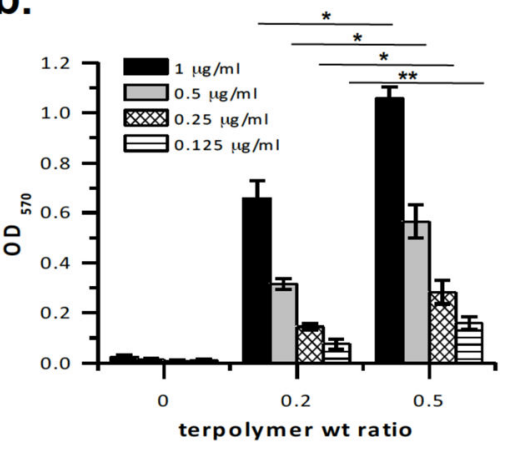

Figure 4.

In vitro $\mathrm{CD}^{+}$and $\mathrm{CD} 8^{+} \mathrm{T}$ cell stimulation mediated by blend particles. $\mathbf{a}, \mathrm{CD} 4^{+} \mathrm{T}$ cell responses and $\mathbf{b}, \mathrm{CD} 8^{+} \mathrm{T}$ cell responses.

DCs were co-incubated with a given amount of particles containing the indicated amount of OVA protein for $4 \mathrm{~h}$. DCs were washed and co-incubated with class II OVA peptide-specific CD4 $4^{+} \mathrm{T}$ cell hybridoma cells for $20-24 \mathrm{~h}$ or the class I OVA peptide-specific $\mathrm{CD} 8{ }^{+} \mathrm{T}$ cellhybridoma cells. The activation of CD4+ or CD8+ T cells was evaluated by the level of IL-2 or the reporter enzyme ( $\beta$-galactosidase), respectively. Experiments were repeated three times and results from a representative experiment are shown. Values are the mean of triplicates \pm s.e. ${ }^{*} \mathrm{p}<0.004 ; * * \mathrm{p}<0.006 ; * * * \mathrm{p}<0.02$. 

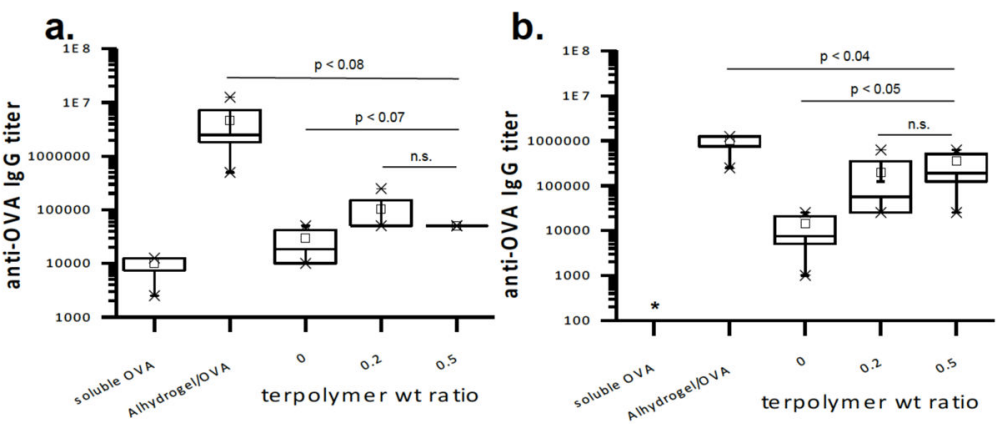

Figure 5.

Blend particles can induce both primary and memory antibody responses in vivo. Mice were immunized with formulations containing $20 \mu \mathrm{g}$ of OVA through hock administration subcutaneously at weeks 0 and 2 . a, Serum antibody responses $3 \mathrm{~d}$ and $\mathbf{b}$, $60 \mathrm{~d}$ after the boost immunization. Each group contained 4-5 mice and experiments were repeated 2-3 times. One representative experiment is shown. 

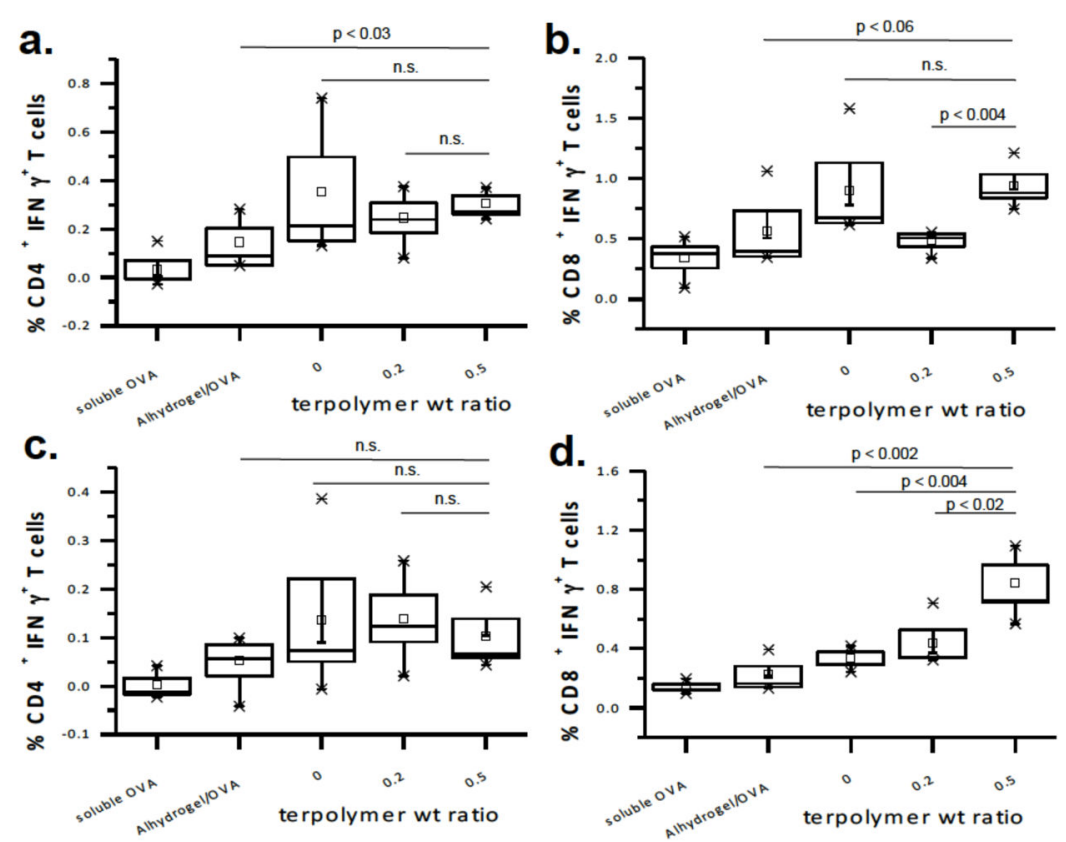

Figure 6.

Blend particles can induce primary $\mathrm{CD} 4^{+}$and $\mathrm{CD} 8^{+} \mathrm{T}$ cell responses in vivo. Mice were immunized with formulations containing $20 \mu \mathrm{g}$ of OVA through hock administration subcutaneously at weeks 0 and $2.3 \mathrm{~d}$ after the boost immunization, antigen-specific CD4+ and CD8+ T cells in the a,b, draining lymph nodes and $\mathbf{c}, \mathbf{d}$, spleen were quantified using flow cytometry, respectively. Each group contained 4-5 mice and experiments were repeated 2 times. One representative experiment is shown.

Student's $t$ test was used to compare different groups. $p<0.05$ is considered as statistically significant. 
a.
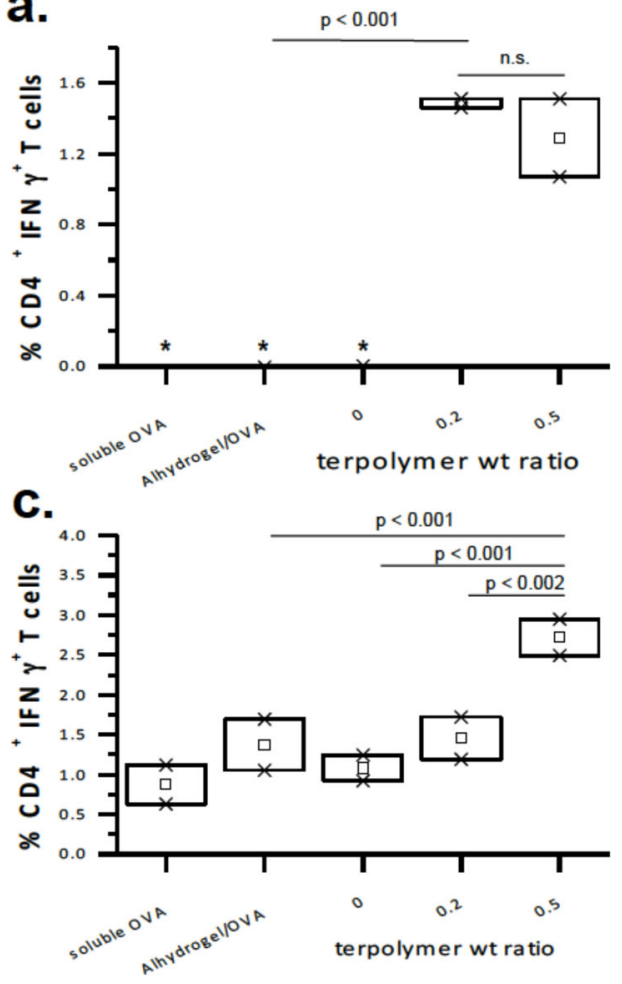

b.

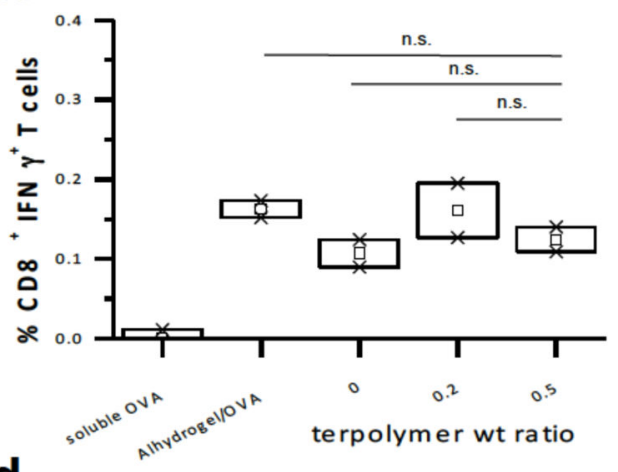

d.

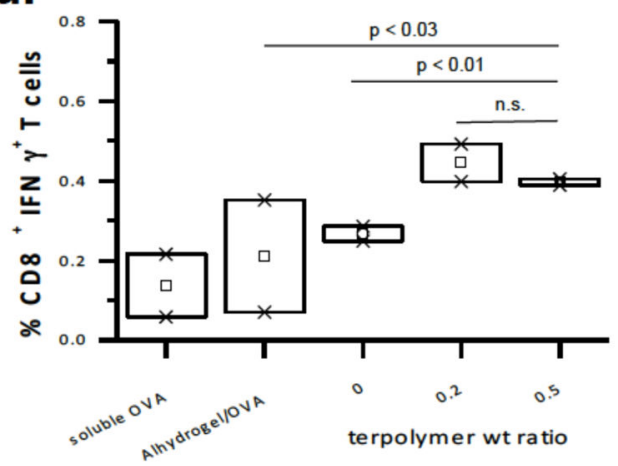

Figure 7.

Blend particles can induce memory $\mathrm{CD}^{+}$and $\mathrm{CD} 8^{+} \mathrm{T}$ cell responses in vivo. Mice were immunized with formulations containing $20 \mu \mathrm{g}$ of OVA through hock administration subcutaneously at weeks 0 and $2.60 \mathrm{~d}$ after the boost immunization, antigen-specific CD4+ and CD8+ T cells in the a,b, draining lymph nodes and c,d, spleen were quantified using flow cytometry, respectively. Each group contained 4-5 mice and experiments were repeated 2-3 times. One representative experiment is shown. Student's t test was used to compare different groups. $\mathrm{P}<0.05$ is considered as statistically significant. n.s. indicates there is no statistical difference between two groups. 

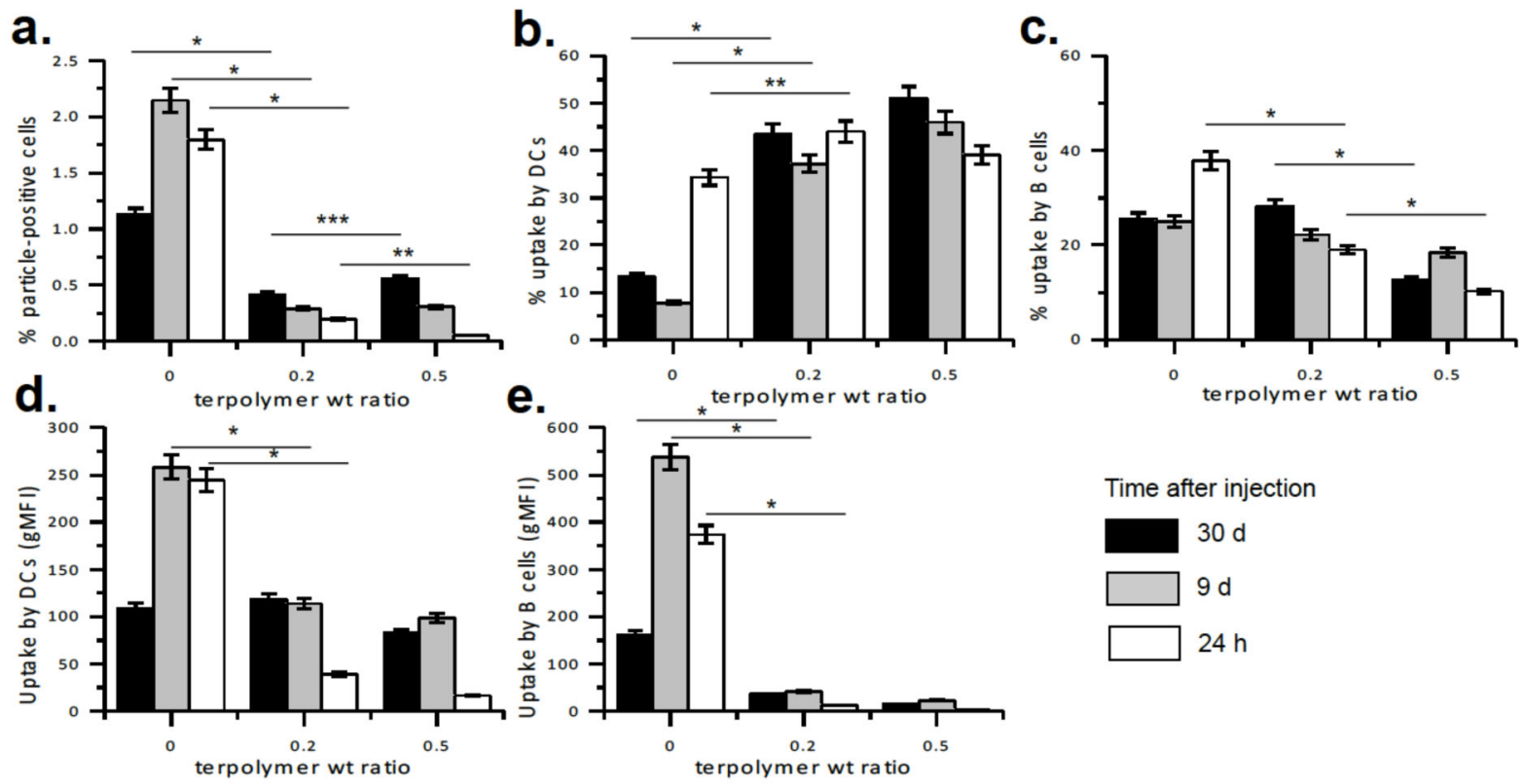

Time after injection

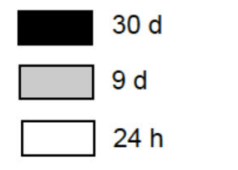

Figure 8.

Uptake of blend particles in vivo after hock injection. Mice were inoculated with $5 \mathrm{mg}$ fluorescently-labeled blend particles via hock administration. At the indicated time points, draining lymph nodes were harvested and analyzed for a, percent of particlepositive cells, percentage of particle-positive cells that were $\mathbf{b}$, DCs $\left(\mathrm{CD} 11 \mathrm{c}^{+}\right), \mathbf{c}, \mathrm{B}$ cells $\left(\mathrm{B} 220^{+}\right)$, and the overall level of uptake by $\mathbf{d}$, DCs and $\mathbf{e}, \mathrm{B}$ cells. Each group contained 3 mice and experiments were repeated 2 times. One representative experiment is shown. Student's $t$ test was used to compare different groups. $* \mathrm{p}<0.01 ; * * \mathrm{p}<0.03 ; * * * \mathrm{p}<0.05$. 


\section{Table 1}

Nuclear Magnetic Resonance spectroscopy and protein loading characterization of blend particles.

\begin{tabular}{cccc}
\hline $\begin{array}{c}\text { Terpolymer used in fabrication } \\
\text { (wt fraction) }\end{array}$ & $\begin{array}{c}\text { BMA hydrogen: glycolide ratio } \\
\text { (from }{ }^{1} \text { H NMR spectra) }\end{array}$ & $\begin{array}{c}\text { Actual terpolymer in particle (wt } \\
\text { fraction) }\end{array}$ & Protein loading.[ $\mathbf{\mu g} / \mathbf{m g}]$ \\
\hline 0 & 0 & 0 & 35.4 \\
0.2 & 0.16 & 0.25 & 42.5 \\
0.5 & 0.42 & 0.47 & 55.5 \\
\hline
\end{tabular}

